\title{
Improving the Legal Environment for Startup Financing by Rationalizing Rule 144
}

Mira Ganor

Follow this and additional works at: http://open.mitchellhamline.edu/wmlr

\section{Recommended Citation}

Ganor, Mira (2007) "Improving the Legal Environment for Startup Financing by Rationalizing Rule 144," William Mitchell Law Review: Vol. 33: Iss. 4, Article 9.

Available at: http://open.mitchellhamline.edu/wmlr/vol33/iss4/9

This Article is brought to you for free and open access by the Law Reviews and Journals at Mitchell Hamline Open Access. It has been accepted for inclusion in William Mitchell Law Review by an authorized administrator of Mitchell Hamline Open Access. For more information, please contact sean.felhofer@mitchellhamline.edu.

(c) Mitchell Hamline School of Law

\section{$\mathrm{MH}$}

MITCHELL HAMLINE OPEN ACCESS setod of lon mitchellhamline.edu 


\title{
IMPROVING THE LEGAL ENVIRONMENT FOR START- UP FINANCING BY RATIONALIZING RULE 144
}

\author{
Mira Ganor ${ }^{\dagger}$
}

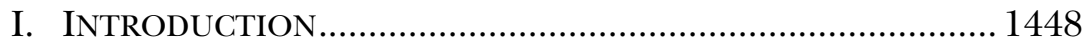

II. LEGAL ENVIRONMENT OF PRIVATE EQUITY FINANCING....... 1455

A. Private Equity Financing............................................... 1455

B. The Securities Rules and the Restrictions on Venture

Capitalists Selling Securities............................................ 1456

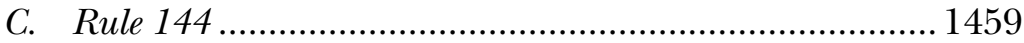

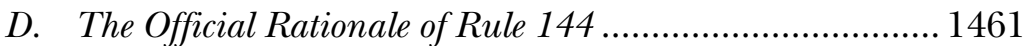

E. The Failure of Rule 144 in Achieving Its Goals ................. 1462

1. Delayed Sales and Public Information.......................... 1463

2. Economic Stake and Length of Investment.................... 1465

3. Market Stabilization and Limitation on Sales .............. 1467

III. Distortions CAUSED BY RULE 144 .................................. 1468

A. Increase in the Cost of Capital............................................ 1469

B. Reduction in Resources Available to Emerging Ventures .... 1470

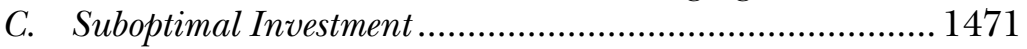

1. Higher Search Costs ................................................. 1473

2. Higher Investigation Costs ........................................ 1473

3. Reduced Monitoring ................................................... 1474

4. Increased Risk of Conflict of Interests ........................... 1474

D. Distortion of the Company's Financing Decisions ............... 1475

1. Delay in Going Public............................................... 1475

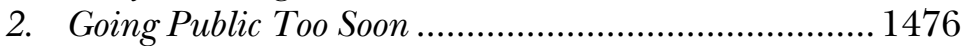

3. Inefficient Choice of Stock Exchange.............................. 1477

IV. TOWARD A MARKET FORCES DRIVEN REGIME ....................... 1479

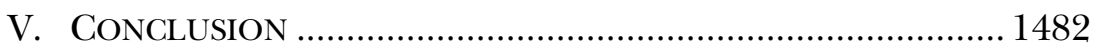

$\dagger$ J.S.D. Candidate, University of California-Berkeley, 2008. I am indebted to Jesse Fried for his invaluable discussions and comments. I would like to also thank Steve Bochner and Stephen Choi for helpful discussions. Comments are welcome and can be sent to me at mganor@boalthall.berkeley.edu. 


\section{INTRODUCTION}

Raising funds is a pivotal task for start-up companies. Private equity $^{1}$ is crucial for start-up companies, especially in the stages before they reach profitability. In these stages of a corporation, other forms of financing, such as debt financing, are rarely accessible. With neither profits nor tangible assets to serve as collateral, start-up companies are unable to attract creditors. ${ }^{2}$ Private equity has been gaining recognition as entrepreneurial, small-scale companies have become more central to economic development in the United States. Studies have shown that during the last two decades, small firms accounted for the majority of newly created jobs. ${ }^{3}$ Additionally, those small firms created the majority of innovations. ${ }^{4}$

Venture capitalists (VCs) not only provide the essential private equity, but are also active investors of start-up companies. VCs mentor and monitor the companies in which they invest. ${ }^{5}$ They offer assistance and support in developing the business of their portfolio companies. VCs also have both the access and expertise needed to conduct effective monitoring.

The distribution of equity, however, is affected by the requirements and restrictions imposed by the law on issuance and transfer of securities. As a general rule, absent an exemption, the law requires companies to register the distribution of securities. Complying with the registration requirement is not only exceptionally time-consuming and costly, but also involves public disclosure of potentially sensitive information. In addition, the

1. Private equity is equity that is not traded on the public markets.

2. See David J. Denis, Entrepreneurial Finance: An Overview of the Issues and Evidence, 10 J. CORP. FIN. 301, 304 (2004) ("Because [start-ups] are typically not yet profitable and lack tangible assets, debt financing is usually not an option.”).

3. See, e.g., Duke K. Bristow et al., Venture Capital Formation and Access: Lingering Impediments of the Investment Company Act of 1940, 2004 Colum. Bus. L. REV. 77, 81 (stating that small businesses "now account for almost all of the new jobs created”); SBA Office of Advocacy, Small Business Resources for Faculty, Students, and Researchers: Answers to Frequently Asked Questions (March 2004), http://www.sba.gov/advo/stats/arsbfaq.pdf (stating that small businesses "[g]enerate 60 to 80 percent of net new jobs annually").

4. See, e.g., Denis, supra note 2, at 301 ("[S]mall firms created more innovations than their large firm counterparts.").

5. See, e.g., id. at 305-07 (reviewing the literature on the relationship between VCs and their portfolio companies); Josh Lerner, Venture Capitalists and the Oversight of Private Firms, 50 J. FinANCE 301 (1995) (studying VCs' monitoring of their portfolio companies). 
preparation of a registration exposes the key participants to substantial liability. ${ }^{6}$

Rule $144^{7}$ under the Securities Act of 1933 plays a key role in facilitating the transfer of securities once the company has become public. Rule 144 provides a safe harbor for sales of unregistered shares to the public. It enables certain investors who purchased shares in a private placement to sell the shares to the public without requiring the company to file a registration statement. In practice, it is impossible to sell to the public unregistered shares of public companies without invoking Rule $144 .^{8}$ Even if the company has a contractual obligation to register the investors' shares when asked, large investors are likely not to exercise this contractual right because of the onerous effect on the company.

While Rule 144 enables investors to avoid the costly registration requirements of the law, it imposes alternative requirements. There are two key limits to the safe harbor of Rule 144: a holding-period restriction and a selling-volume restriction. ${ }^{9}$ Rule 144 imposes a holding period of one year for shares that investors acquired in a private placement. ${ }^{10}$ The holding period begins when the shares have been purchased and fully paid. ${ }^{11}$ The selling-volume restriction limits the amount of shares that can be sold following the expiration of the one-year holding period. ${ }^{12}$ Each shareholder can sell shares under Rule 144 only up to an amount that, when added together with the shareholder's sales in the previous three months, will not exceed a certain maximal amount. $^{13}$ This maximal amount is either one percent of the company's outstanding shares or the average reported weekly volume of trading of the company's securities during the preceding four weeks, whichever is greater. ${ }^{14}$

6. See 1 Thomas Lee Hazen, Treatise on the LaW OF Securities Regulation $\S 1.6$ (5th ed. 2005).

7. 17 C.F.R. $\$ 230.144$ (2006).

8. See Harold S. Bloomenthal, Securities Law Series, Going Public Handbook, Going Public, the Integrated Disclosure System and Exempt FINANCING 100 (2002).

9. 17 C.F.R. $§ 230.144(\mathrm{~d})-(\mathrm{e})$.

10. Id. $§ 230.144(\mathrm{~d})(1)$.

11. Id. In the case of options, the date the option is exercised, rather than the date the option is granted, marks the beginning of the holding period for the share issued pursuant to the option.

12. See id. $\$ 230.144(\mathrm{e})$.

13. Id.

14. Id. § 230.144(e) (1) (i)-(iii). 
Despite the widespread use and importance of Rule 144 in the business world, there has been little academic legal analysis of it. The academic legal literature often refers to its restrictions but mostly only as an example of diverse regulatory practices and not as the main focus of attention. ${ }^{15}$

In 1988, Steinberg and Kempler offered a detailed examination of the requirements of Rule 144 and expressed concern about the magnitude of its safe harbor requirement. ${ }^{16}$ They argued that Rule 144 is excessively permissive because after a certain holding period it allows non-affiliates ${ }^{17}$ to sell restricted shares $^{18}$ without being subject to the selling-volume restriction. ${ }^{19}$ They reasoned that "the detrimental effect on the capital trading markets and the investing public are identical, irrespective of whether one has affiliate status when reselling large quantities of stock." 20

This article, in contrast, argues that the selling-volume and holding-period restrictions should be abolished rather than extended. It shows that the selling-volume and holding-period restrictions of Rule 144 are not efficient and do not achieve their anticipated goal. ${ }^{21}$ Furthermore, it shows that Rule 144 has

15. See, e.g., Ronald Gilson, Drafting an Effective Greenmail Prohibition, 88 Colum. L. Rev. 329, 335 (1988) (using Rule 144 as an example of the regulatory use of holding periods to deter exploitive investments); Ellen Taylor, Teaching an Old Law New Tricks: Rethinking Section 16, 39 ARIZ. L. REV. 1315, 1336 (1997) (using Rule 144 as one example of the redundancy of section 16(b) of the Securities Exchange Act of 1934); Stephen Choi, Regulating Investors Not Issuers: A Market-Based Proposal, 88 CAL. L. ReV. 279, 307 (2000) (using Rule 144 as an example of the failure of the securities regulations to protect the unsophisticated public investors).

16. See Marc I. Steinberg \& Joseph P. Kempler, The Application and Effectiveness of SEC Rule 144, 49 OHio ST. L.J. 473 (1998).

17. An affiliate of an issuer is defined in 17 C.F.R. $\$ 230.144$ (a) (1) (2006) as "a person that directly, or indirectly through one or more intermediaries controls, or is controlled by, or is under common control with, such issuer." Id.

18. Restricted shares are shares acquired in unregistered private sales. See id. $\S 230.144(\mathrm{a})(3)(\mathrm{i})$.

19. See Steinberg \& Kempler, supra note 16. The current holding period of Rule 144, after which non-affiliates are no longer subject to the selling-volume restriction, is two years starting from the date of purchase of the stock. The holding period was originally three years until the SEC shortened the duration to two years in 1997. See Press Release, Securities and Exchange Commission, Revision of Holding Period Requirements in Rules 144 and 145 (February 20, 1997), available at http:/ / www.sec.gov/rules/final/33-7390.txt.

20. See Steinberg \& Kempler, supra note 16, at 500.

21. See infra Part II.E. 
distorting effects. ${ }^{22}$ Thus, this article presents the opposite conviction-the selling-volume restriction should not restrict any shareholder, regardless of whether such shareholder is an affiliate or non-affiliate. Market forces, rather than statutory restrictions, are likely to achieve a more efficient outcome that will eliminate the distorting effects of Rule 144.

Both the holding-period restriction and the selling-volume restriction impair investor liquidity. The restrictions force shareholders to wait one year before they are allowed to sell their shares, even though a market for their shares may already exist. And once they are permitted to sell shares, they may do so only to the extent allowed by the selling-volume restriction.

In this article, I show that the liquidity-reducing effects of Rule 144 distort the financing of start-ups. Rule 144 provides inefficient incentives and increases the cost of raising capital. This is because Rule 144 is likely to restrict the amount an investor is willing to invest in a single company. The selling-volume restriction allows each restricted shareholder to sell the same amount regardless of how many shares one owns. Thus, the last share purchased by an investor bears a much higher liquidity risk than the first share. After investing a significant amount in a company, an investor considering purchasing additional shares is unlikely to be able to rely on Rule 144's safe harbor for future sale of these shares. Rule 144, therefore, discourages potential investors from investing substantial amounts in one company.

Thus, Rule 144 provides at least some explanation for a puzzling empirical finding. Researchers were surprised to learn that, while VCs' total investment more than doubled during the 1980 s, the average size of their investments increased by only forty percent. $^{23}$ The selling-volume restriction of Rule 144 likely contributed to the VCs' inefficient decision to refrain from further increasing their investment in a single company.

As a result of the selling-volume restriction of Rule 144, the number of investors a company needs for financing increases. The number of companies in which an investor invests increases, as

22. See infra Part III.

23. See, e.g., George W. Fenn et al., The Economics of the Private Equity Market, 29 Bd. of Governors of THe Fed. Reserve Sys., StafF Studies Series No. 168 (1995), available at http://www.federalreserve.gov/pubs/staffstudies/1990-99/ss168.pdf ("Somewhat surprisingly, data on investments suggest only moderate shifts toward larger investments and investments in later-stage new ventures.”). 
well. Generally, it is preferable and more cost-efficient, however, to have subsequent investment by the same investor. Subsequent investments lower search and monitoring costs.

Reduction in the amount a company can raise from a single investor increases transaction and search costs for both the company and the investors. The investors are likely to look for multiple potential investments and closely inspect a number of companies. Reinvesting in the same company, in contrast, would have required much less inspection, if any. At the same time, the company has to look for additional potential investors, cooperate in several due-diligence processes, and coordinate multi-party negotiation processes, all of which are time-consuming and costly.

Increase in the number of investors that invest in the same company has a negative effect on the monitoring of the company. Studies have shown that VCs are uniquely positioned to play an important role in the governance of their portfolio companies and that the VCs are participating in monitoring activities. ${ }^{24}$ Monitoring a company, however, is a costly activity. And the lower the stake an investor has in a company, the lower the investor's personal benefits are from its own monitoring activities. Thus, since Rule 144 decreases the amount an investor is willing to invest in a single company, it is also likely to lead to suboptimal levels of monitoring.

In addition, Rule 144 can distort the financing decisions of the company. By causing investors to hesitate to refinance and by increasing the cost of raising private equity, Rule 144 can force the company to go public too soon. The choice of delaying public registration might not be available to the company because Rule 144's restrictions rendered this choice economically prohibitive. The company, however, might still be in a stage in which the benefits of staying private surpass those of going public.

Alternatively, the company might be forced by its investors not to go public even at a time when going public is the most efficient strategic choice. Investors are likely to prefer a different means of exit, such as a merger or an acquisition, to avoid Rule 144's restrictions. Rather than go public and become subject to the onsale restrictions of Rule 144, investors looking for liquidity may even prefer to sell the company at a cost lower than the valuation of

24. See Denis, supra note 2, at 305 (reviewing the literature on the relationship between VCs and their portfolio companies). 
the company suggests.

Furthermore, Rule 144 influences the company's choice of stock exchange on which it will trade once it is public. This influence occurs because Rule 144 sets the amount that may be sold under the safe harbor based on the trading volume of the company's stock. ${ }^{25}$ The different trading methods of the stock exchanges cause similar transactions to result in different reports of trading volumes. ${ }^{26}$ Thus, Rule 144 encourages companies to favor the stock exchange where higher volume of trading is reported. Empirical studies found that Rule 144 influences the choice of the stock exchange. ${ }^{27}$ According to these studies, companies often choose the Nasdaq as the venue for their initial listing. Companies traded on the Nasdaq often do not transfer their shares to the New York Stock Exchange (NYSE) because of Rule 144, despite the potential increase in share value associated with listing on the more prestigious NYSE and lower trading costs.

Because of these undesirable effects of Rule 144, I suggest eliminating both the selling-volume restriction and the holdingperiod restriction. This change will remove the illiquidity costs that investors incur and will lower the cost of capital for start-ups. Moreover, both the holding-period restriction and the sellingvolume restriction of Rule 144 undermine the main purpose of the law-to secure full and fair disclosure and to provide current information to the public. Artificially limiting the sale of restricted shares held by sophisticated investors reduces the availability of information about the firm by camouflaging the value that these investors assign to the company. If these investors were permitted

25. See 17 C.F.R. $\$ 230.144$ (e) (1) (ii)-(iii) (2006).

26. See Kam-Ming Wan, The Effect of Insider Restricted Equity on the Choice of Exchange: An Empirical Study of the NYSE Listing Choices of NASDAQ Firms, SSRN Elec. PAPer Coll. No. 268010, at 3 (2001) available at http://ssrn.com/abstract $=268010$ ("Nasdaq trading volume typically measures higher than NYSE trading volume for similar transactions."); Anne Anderson, Edward Dyl \& Laurie Krigman, Rule 144 and the IPO Exchange Listing Decision 4 (Feb. 2004) (unpublished working paper, on file with author) ("Nasdaq is a dealer market, whereas the NYSE is largely an auction market. ... [T] he reported trading volume for a stock will be much higher when the stock trades in a dealer market than when it trades in an auction market.").

27. See Wan, supra note 26, at 11 (illustrating how "the combination of the rule 144 and inflated trading volume on the Nasdaq give corporate insiders an option value to resell more of their company equities when their company is listed on the Nasdaq instead of on the NYSE"); see also Anderson et. al., supra note 26, at 13 (reporting that "SEC Rule $144 \ldots$ appears to affect the listing decisions of firms that are going public"). 
to sell, a decision not to sell may indicate that they value the company at least as much as the price for which it is traded. On the other hand, a decision to sell, absent liquidity constraints, would mean that the sophisticated investors believe that the market overvalues the company.

Furthermore, since the initial public offering (IPO) registration statement includes a detailed account of the restricted shares purchased prior to the IPO, ${ }^{28}$ it should not come as a surprise if restricted shares enter the market. A sale of such shares following the completion of the IPO process does not seem to harm the public, since it should expect such transactions. Thus, eliminating Rule 144's restrictions does not compromise the purposes for which it was promulgated. And the holding-period restriction may even hurt the retail investors, since the detailed disclosures of the registration statement and the prospectus become less accurate with the lapse of time. Therefore, allowing a sale of restricted shares to take place as early as possible may result in a more informed purchase transaction than a sale conducted after one year has elapsed.

If, however, efficiency considerations require investors to limit the sale of shares purchased prior to the IPO, market forces will implement such limitations. And the company itself is best suited to distribute selling rights among its restricted shareholders. Each company should, therefore, be allowed to determine whether such sale should be permitted and, if so, under what limitations. This change will promote an efficient allocation and pricing of selling rights. Eliminating Rule 144's restrictions will thus provide a more efficient investment incentive structure, reduce the disincentive to invest large amounts in a single company, and lessen the costs of raising capital.

First, I provide a brief description of the current legal arena, which is the setting for the discussion offered by this article. ${ }^{29}$ The official rationale for Rule 144, along with a discussion of the failure of Rule 144 to fulfill its intended goals, is also presented. In particular, this article elaborates on the two requirements of Rule 144 that should be eliminated-the selling-volume restriction and holding-period restriction. Next, it discusses the distorting effects of those requirements. ${ }^{30}$ Finally, this article questions the

28. 15 U.S.C. § 77aa (2000).

29. See infra Part II.

30. See infra Part III. 
justification for the imposition of any on-sale restrictions following the IPO. ${ }^{31}$ It presents the argument for a market-forces regime in place of the rigid and inefficient selling-volume and holding-period restrictions of Rule 144. It concludes that the two main restrictions of Rule 144 should be abolished because of the significant burdens they impose on emerging ventures. ${ }^{32}$

\section{LEGAL ENVIRONMENT OF PRIVATE EQUITY FINANCING}

With the growing importance of small firms, private equity's fundamental contribution to the economic development is becoming increasingly evident. Section A of this Part describes the important role of private equity financing in the development of small firms and new businesses. This section further describes the value-added nature of VCs' investments, which are far from being limited to the supply of much needed capital.

The remainder of this Part describes certain aspects of the legal environment that control private financing. Section B provides a general overview of the securities rules that affect every equity transaction and focuses on their application to VCs wishing to sell securities. It also describes the historical background of the development of these rules. Section $\mathrm{C}$ focuses on the safe harbor of Rule 144. The section provides a description of the salient features of the selling-volume and holding-period restrictions of Rule 144, which are especially relevant to private equity financing.

Section D further details the main concerns that Rule 144 was designed to address. In addition, it describes how Rule 144 chose to deal with these concerns. Finally, section E discusses the failure of Rule 144 to achieve its goal. It also shows that Rule 144 is likely to aggravate some of the problems it was meant to solve and is likely to create additional problems.

\section{A. Private Equity Financing}

Entrepreneurial ventures are faced with the challenging task of securing funds for their operations. At the early stages, before they reach profitability or obtain assets that can be used as valuable collateral, those companies almost exclusively rely on private equity.

31. See infra Part IV.

32. See infra Part V. 
Studies have found a significant rise in the amount of capital allotted to the private equity market. ${ }^{33}$ At the same time, there has been a rise in the importance of entrepreneurial ventures to economic development. For the last two decades, small firms have been responsible for the creation of the majority of new jobs and the majority of innovations. ${ }^{34}$

VCs provide entrepreneurial ventures with crucial capital needed for the daily operations and growth. Though not the exclusive source for private equity, VCs are a dominant source of capital for emerging companies that passed the seed stage (the initial early stage of development). ${ }^{35}$

VCs are also active investors; in addition to providing valuable capital, they are providing their portfolio companies with added value. The literature has identified three main types of roles that VCs assume in order to help their portfolio companies. ${ }^{36}$ Under the first role, VCs offer their portfolio companies a range of support services that assist in building the internal organization of the companies and in marketing the companies' products. ${ }^{37}$ They are particularly influential in the development of the companies' business plans. VCs are also well known for being instrumental in forming strategic alliances.

The second important role that VCs assume is that of monitoring. ${ }^{38}$ As part of their governance activities, the VCs frequently visit their portfolio companies, often serve on the boards of such companies, and are involved in shaping the top management team. The third role of VCs is certifying the quality of the start-ups in which they have invested. ${ }^{39}$ The VCs' reputation often helps the companies to raise additional funds.

\section{B. The Securities Rules and the Restrictions on Venture Capitalists Selling}

33. See, e.g., Denis, supra note 2, at 301-02 (reporting the amounts committed to venture capital funds in the years 1992-2001).

34. Id. at 301 (describing the importance of small firms to the U.S. economy).

35. Id. at 304 ("[E]ntrepreneurs tend to rely on three primary sources of outside equity financing: venture capital funds, angel investors, and corporate investors. . . . [A]ll three sources contribute a substantial amount of capital to entrepreneurial firms.”).

36. Id. at 305-07 (reviewing the literature on the relationship of VCs and their portfolio companies).

37. Id. at 306 .

38. Id. at 305-06.

39. Id. at 306-07 (reviewing the literature on VCs certifying the quality of their portfolio companies). 


\section{Securities}

The stock market collapse of 1929 and the Great Depression that followed were partially blamed on securities fraud. ${ }^{40}$ Such fraud included abuse of holding companies, insider trading, and accounting scandals. This led to the realization that federal legislation was needed. ${ }^{41}$ Congress enacted the Securities Act of 1933 (1933 Act), which is also known as the "Truth in Securities" Act. ${ }^{42}$ The 1933 Act intended to provide adequate protection to investors by disclosing, fully and fairly, all the aspects of the marketed securities. ${ }^{43}$

The 1933 Act is directed primarily at the distribution of securities, the process by which securities are first offered to the public. Generally, the 1933 Act requires the registration of all securities being distributed, either directly by the issuer or indirectly by an investor in a secondary distribution (i.e., a distribution of shares previously issued by the company to the selling shareholders). In the year that followed, Congress enacted the Securities Exchange Act of 1934 (1934 Act), which was intended to regulate all aspects of publicly traded securities. ${ }^{44}$

In order to comply with the registration requirement, the company has to file a registration statement, which is a disclosure document, with the Securities and Exchange Commission (SEC). ${ }^{45}$ The filing of the registration statement potentially discloses sensitive confidential information on the company. In addition, the process of preparing a registration statement is not only expensive and time consuming, but also exposes the key participants in the registration to substantial liability for failing to

40. See, e.g., 1 HAZEN, supra note 6 , $\$ 1.2$; see also Shearson/Am. Express, Inc. v. McMahon, 482 U.S. 220, 251 (1987) ("[The Securities] Act was passed in 1933 . . . in response to the market crash of 1929. The Act was designed to remedy abuses in the securities industry, particularly fraud and misrepresentation by securitiesindustry personnel, that had contributed to that disastrous event.").

41. See, e.g., Paul M. Clikeman, The Greatest Frauds of the (Last) Century, New ACCT., May 2003 (describing the major accounting frauds of the twentieth century, including the Kreuger \& Toll fraud, and noting that such frauds lead to the enactment of the securities acts of 1933 and 1934), available at http:// www.newaccountantusa.com/newsFeat/wealthManagement/Clikeman_Greatest_ Frauds.pdf.

42. See 1 HAZEN, supra note $6, \S 1.2$.

43. See id.

44. See id. \$§ 1.1-.2; see also Securities Exchange Act of 1934, 15 U.S.C. $§ 78 \mathrm{a}$ (2000 \& Supp. 2004).

45. See 1 HAZEN, supra note $6, \S 1.6$. 
comply strictly with the disclosure requirements. ${ }^{46}$ Thus, the company will prefer to avoid filing a registration statement and will be reluctant to register the investors' shares. Furthermore, the company's own plans for raising capital might be negatively affected by a registration of the investors' previously issued shares.

Absent a contractual right, an investor might not be able to convince the company to register its shares with the SEC. In the customary investment agreements, the company grants the investors a right to force the company to register the investors' shares. This right, which is called a demand right, is customarily limited both in how often it can be exercised and in the ability to exercise. Usually no more than three demand rights are granted, and only investors that hold a majority of the class shares are allowed to initiate such exercise. ${ }^{47}$

In practice, however, demand rights are rarely exercised. ${ }^{48}$ The choice not to exercise these rights is likely to result from both the high costs that the company would incur from such exercise and the lack of managerial support for the registration. The investor, though wishing to sell its shares, is interested in the cost of such sale to the company. This is because such cost affects the price the investor can receive for the shares and the value of any shares it might decide not to sell. In addition, managerial support is important to the success of a registration. ${ }^{49}$ Also, in an underwritten registration in which numerous shares are sold, as opposed to a gradual sale of shares to the market, underpricing of the stock is likely to occur. Thus, even the receipt of a contractual right to register one's shares by the company does not render the registration option a viable one for an investor who wishes to sell its shares. Despite the fact that the rights to demand registration are typically not going to be exercised, investors insist on being granted these rights for a different reason-to obtain future leverage against the company and not in order to be able to register the

46. Id.

47. See, e.g., Richard A. Mann et al., Starting from Scratch: A Lawyer's Guide to Representing a Start-Up Company, 56 ARK. L. REv. 773 (2004) (describing the terms of a typical VC financing transaction).

48. See, e.g., D. Gordon Smith, Venture Capital Contracting in the Information Age, 2 J. SMALl \& EMERGing Bus. L. 133, 151 (1998) (describing the registration rights in venture capital financing agreements).

49. See 1 Joseph W. Bartlett, Equity Finance: Venture Capital, Buyouts, REstructurings, AND REORGANIZATIONS § 9.4, at 195 (2d ed. 1995). 
shares in the future. ${ }^{50}$

The 1933 Act provides certain exemptions from its registration requirement. $^{51}$ The section $4(1)$ exemption, ${ }^{52}$ also known as the exemption for non-professionals, was designed to facilitate the dayto-day trading transactions between individual investors with respect to securities already issued, rather than the distribution of securities. The section 4(1) exemption allows most of the day-today trading between investors on the exchanges and the over-thecounter markets to take place. It provides a registration exemption for transactions by any person other than an issuer, underwriter, or dealer. ${ }^{53}$ Generally, the 1933 Act defines an underwriter as anyone who purchases a security from the issuer with a view to distribute the security (including anyone who indirectly participates therein).$^{54}$ One key criterion in determining whether a security was purchased with a view toward distribution is whether the would-be underwriter had sufficient investment intent at the time of purchase. ${ }^{55}$

The case law, the SEC's interpretation of what the Act deems an underwriter, and the scope of the exemption under section 4(1) have not provided much practical guidance for the sale of restricted securities. Each decision as to whether the registration requirement was triggered required an analysis of all the particular circumstances and was very fact specific. ${ }^{56}$ The decisions regarding those issues were frequently confusing and often appeared inconsistent. ${ }^{57}$

\section{Rule 144}

In 1972, in order to clear some of the uncertainty, the SEC promulgated Rule $144,{ }^{58}$ which provides some guidance for

50. See Douglas G. Smith, The Venture Capital Company: A Contractarian Rebuttal to the Political Theory of American Corporate Finance?, 65 TENN. L. REv. 79, 130 (1997) ("Although there may be practical constraints on the exercise of demand registration rights, they still may be utilized as leverage over management of the portfolio company.").

51. See 1 HAZEN, supra note $6, \S \S 4.1, .21$.

52. See Securities Act of $1933 \S 4(1), 15$ U.S.C. $§ 77 d(1)$ (2000).

53. Id.

54. Id. § 2(11), 15 U.S.C. $\$ 77 \mathrm{~b}(\mathrm{a})(11)$.

55. See 1 HAZEN, supra note $6, \S \S 4.23-.24$.

56. See id. at 256 ("The one clear lesson of the cases and SEC decisions is that section 2(11)'s definition of underwriter is a trap for the careless and unwary.").

57. Id. $\$ 4.26$.

58. 17 C.F.R. $§ 230.144$ (2006). 
answering the question of who is an underwriter and thereby defines the scope of the statutory exemption under section 4(1). Rule 144 is not the exclusive method by which restricted securities may be sold in reliance on an exemption. But reliance on precedents, rather than on Rule 144, imposes a substantial burden of proof to establish that an exemption is available. ${ }^{59}$ In fact, " $[\mathrm{t}] \mathrm{he}$ liberality of the rule and the attitudes of the Commission, issuers and their counsel generally have made sales of restricted securities of public reporting companies outside of Rule 144 imprudent or impossible."

Rule 144 provides a safe harbor to investors who purchased their shares in a transaction not involving a public offering, such as transactions that occurred prior to the IPO in an unregistered private placement. ${ }^{61}$ The safe harbor allows such investors to sell their shares to the public without registering those shares with the SEC, as required by section 5 of the 1933 Act, ${ }^{62}$ subject to certain limitations. ${ }^{63}$ The two main limitations are: (1) time restrictions and (2) volume restrictions. ${ }^{64}$ Section (d) of Rule 144 allows sales only following the lapse of a holding period-one year beginning from the date of purchase. ${ }^{65}$ Section (e) of Rule 144 allows each restricted shareholder to sell restricted shares only up to a restricted amount. ${ }^{66}$ This amount of restricted shares, together with the amount of restricted shares that the shareholder sold during the preceding three months, shall not exceed the greater of one percent of the outstanding shares or the average reported weekly volume of trading ${ }^{67}$ in the securities during the preceding four calendar weeks. ${ }^{68}$

\footnotetext{
59. See 1 HAZEN, supra note $6, \S 4.26$.

60. See BloOMENTHAL, supra note 8 , at 100.

61. 17 C.F.R. $\$ 230.144$.

62. Securities Act of $1933 \S 5,15$ U.S.C. $§ 77$ e (2000).

63. See 17 C.F.R. $§ 230.144(d)-(e)$.

64. Id.

65. Id. $\S 230.144(\mathrm{~d})$.

66. Id. $\S 230.144(\mathrm{e})$.

67. In order for the safe harbor to apply, the class of shares sold must be listed on a stock exchange or quoted on Nasdaq, not merely traded over the counter.

68. Id. $\$ 230.144$ (e) (1) (i)-(iii). It should be noted that shareholders who are not affiliates of the company may freely sell their restricted shares after the lapse of another year following the expiration of the one year holding period. Affiliates are also subject to the one year holding period. Id. $§ 230.144(\mathrm{~d})(1)$. Affiliates, however, are always restricted by the volume limitation, even after the lapse of two years and even if they wish to sell shares acquired in the public market after the
} 


\section{The Official Rationale of Rule 144}

The Preliminary Note to Rule 144 describes the concerns that Rule 144 intended to address. ${ }^{69}$ The restrictions to the safe harbor of Rule 144 attempt to resolve three major concerns. First, Rule 144 was designed to implement the purpose of the 1933 Act under which it was promulgated - to provide full and fair disclosure to the public and prevent fraud in the sale of securities. ${ }^{70}$ Thus, Rule 144 was designed to protect investors by preventing the creation of public markets in securities absent adequate current information concerning the issuer. In order to achieve this purpose, Rule 144 requires current public information about the company as a condition of the use of the safe harbor. ${ }^{71}$ Rule $144(\mathrm{c})$ states that the safe harbor is available only if the company complies with the periodic reporting requirements of the 1934 Act. $^{72}$ In addition, Rule 144(h) requires a shareholder that uses the safe harbor to file a notice with the SEC if the sales exceed a certain threshold. ${ }^{73}$ Rule 144 allows submitting the notice concurrently with the sale. ${ }^{74}$

Second, the holding-period restriction of Rule 144 was designed to ensure that the restricted shareholders have personally assumed the economic risks of their investment at the time they purchased the shares and are not acting on behalf of the company as its underwriters. ${ }^{75}$ This is because the safe harbor under Rule

IPO. Id. $§ 230.144(\mathrm{k})$.

69. Preliminary Note to Rule 144, 17 C.F.R. $§ 230.144$ (2006).

70. Id.

71. See 17 C.F.R. \$ 230.144(c).

72. Id. $\S 230.144(\mathrm{c})(1)$. Because the availability of the safe harbor is subject to the company fulfilling its reporting requirements under the 1934 Act, customary investment agreements include a provision that contractually obligates the company to comply with all the necessary requirements to allow the investors to use Rule 144's safe harbor. See Smith, supra note 50, at 131 ("Registration rights provisions often state that the portfolio company will make all filings or take other actions necessary to allow venture capital investors to sell their shares . . . in the public market pursuant to Rule 144 of the Securities Act of 1933.”).

73. Id. $\S 230.144(\mathrm{~h})$. The threshold for the current filing requirement is a sale of more than 500 shares or proceeds of an aggregate dollar amount greater than $\$ 10,000$ in any three-month period. $I d$.

74. Id. To be sure, an advance-notice requirement, along the lines of the proposal by Jesse Fried, to require insiders to disclose their intended trading shortly beforehand in order to reduce profits from insider trading, would help achieve a more transparent and efficient securities market. See Jesse Fried, Reducing the Profitability of Corporate Insider Trading Through Pretrading Disclosure, 71 S. CAL. L. REV. 303 (1998).

75. Preliminary Note to Rule 144, 17 C.F.R. $§ 230.144$. 
144 is intended to exempt transactions between individual investors from registration and not to exempt sales by the company to the public. ${ }^{76}$ Sales by the company to the public, on the other hand, require full compliance with the registration provisions of the Act in order to protect the public.

Third, the selling-volume restriction of Rule 144 was designed to allow only routine trading transactions, as permitted under section 4(1) of the Act, rather than distributions. ${ }^{77}$ A distribution is a public offering and usually involves a large amount of securities. ${ }^{78}$ This restriction is concerned with the impact of the transaction on the market and limits the quantities allowed to be sold, in any given time, to avoid disrupting the market. Thus, the ceiling set by the selling-volume restriction is linked to the volume of trading of the stock. ${ }^{79}$ The volume of trading of a stock plays an important role in trading. It is an important role because the ratio of the size of a transaction to the trading volume is an indicator of the impact the transaction will have on the price of the stock. The higher the ratio, the greater the price pressure caused by the transaction. ${ }^{80}$

\section{E. The Failure of Rule 144 in Achieving Its Goals}

Section D described the objectives of the regulator in promulgating Rule 144. This section will show that Rule 144 does not succeed in fulfilling its intended goals. First, while Rule 144 is intended to promote the availability of information to the public, the restrictions of the Rule are likely to result in less informed sales. Second, because Rule 144 ignores the general assumption of economic risk by private investors, it excessively restricts

76. Excluding from the safe harbor sales by issuers and underwriters is consistent with the exemption of section 4(1) of the 1933 Act, under which Rule 144 was promulgated. See supra text accompanying note 53.

77. Preliminary Note to Rule 144, 17 C.F.R. $\$ 230.144$.

78. See 1 HAZEN, supra note 6, § 4.24; see also Ackerberg v. Johnson, 892 F.2d 1328, 1335 n.6 (8th Cir. 1989) (stating that a distribution is "in turn . . . considered the equivalent of a public offering").

79. $\quad$ See 17 C.F.R. § 230.144(e) (1) (ii)-(iii).

80. Microcap companies are companies with low capitalization. Because of low volumes of trading, "microcap companies" provide an extreme example of the connection between trading volume and the effect of trade on the price of the stock. In an SEC guide for investors, the SEC warns the public of the risks of investing in microcap companies, citing as one of these risks the extreme sensitivity of the stock price to trading because of the low volume of trading. See U.S. Securities AND Exchange Commission, Microcap Stock: A Guide for INVESTORS (2004), http://www.sec.gov/investor/pubs/microcapstock.htm. 
transactions. Third, whereas Rule 144 attempts to promote market stability, it fails to contribute efficiently to this goal.

\section{Delayed Sales and Public Information}

Contrary to Rule 144's intent to assure that the public has current information about the company when it purchases shares, the restrictions of the rule may negatively affect the information the public has at the time of the sale. After the selling restrictions of Rule 144 expire, the public is likely to be less informed than it is at the time of the IPO (or secondary offering) because substantial time has passed since the filing of the registration statement. The detailed disclosures of the registration statement and the prospectus become less accurate with the lapse of time. Following the IPO, the press, analysts, and certain sophisticated investors usually manage to acquire access to some new information about the company, but such information is limited in scope and accuracy in comparison to the disclosures that the company is required to make as part of the registration process. The company is under no obligation to assist in the exposure of such new information. The company's cooperation, however, is likely to be offered to the underwriters who engage in a due diligence process as part of the preparation of the registration, since all of the participants preparing the registration statement, and especially the company, are liable for misstatements or omissions.

Even though Rule 144(c) requires that updated information about the company will be available, the registration statement provides more information and is subject to the scrutiny of the underwriters' counsels and auditors who perform a due diligence review of the company. Rule $144(\mathrm{c})$ requires only that the company comply with the reporting requirements of the 1934 Act, ${ }^{82}$ which are basically periodic disclosure requirements with some exceptions, such as Form 8-K reporting requirements of extraordinary corporate events. ${ }^{83}$

81. See Securities Act of $1933 \S 11,15$ U.S.C. $§ 77 \mathrm{k}$ (2000); see also 1 HAZEN, supra note $6, \S 7.3$.

82. 17 C.F.R. $\$ 230.144(c)$

83. In 2002, the SEC expanded the scope of the 8-K filing of material events of corporate changes and shortened the filing deadline in a move away from a periodic disclosure regime toward a materiality regime of real-time disclosure mandated by the Sarbanes-Oxley Act. Sarbanes-Oxley Act of 2002, $\S 409$, Pub.L.107-204 (2002). For the SEC's rule regarding Additional Form 8-K Disclosure Requirements and Acceleration of Filing Date, see 69 Fed. Reg. 15,594 
The periodic reporting is less detailed and subject to less scrutiny than the registration statement. The periodic reporting is literally periodic, triggered by the passage of time rather than the occurrence of material events. ${ }^{84}$ Generally, there is no duty to disclose new information, beyond extraordinary corporate events, between the reports. ${ }^{85}$ In addition, the scope of most of the periodic reports is limited, and the quarter financial reports are not required to be audited. ${ }^{86}$ Thus, allowing a sale of restricted shares as early as possible and in particular, prior to the expiration of the holding period, may result in a more informed purchase transaction than a sale taking place after a year has expired.

Furthermore, before the selling restrictions expire, the original investors' sentiments about the value of the stock relative to the market price are camouflaged. By artificially delaying sales, Rule 144 impedes the ability of the market price to reflect the valuations attributed to the stock by the entire market. Unsophisticated investors are likely to misinterpret the fact that the original shareholders retain their holdings in the company as a sign of the original investors' sentiments about the company, rather than as a product of a legal restraint. The holding-period restriction as well as the selling-volume restriction undermine the main purpose of Rule 144, namely to secure full and fair disclosure and to provide current information to the public. Artificially limiting the sale of the restricted shares (by delaying it, as the holding-period restriction does, or-and this is practically also a partial delay-by rationing the amount that may be sold at each given time, as the selling-volume restriction does) is hindering the availability of information about the real sentiments of the

(Mar. 25, 2004) ("We are adding eight new items to the list of events that require a company to file a current report on Form 8-K . . . These amendments . . . shorten the Form 8-K filing deadline . ... These amendments are responsive to the 'real time issuer disclosure' provision in Section 409 of the Sarbanes-Oxley Act of 2002. They are intended to provide investors with better and faster disclosure of important corporate events.").

84. See Steven E. Bochner \& Samir Bukhari, The Duty to Update and Disclosure Reform: The Impact of Regulation FD and Current Disclosure Initiatives, 7 STAN. J. L. BuS. \& Fin. 225, 228 (2002) ("Under the federal securities laws, materiality does not automatically translate into an obligation to disclose information; a duty must exist. As succinctly put by the U.S. Supreme Court in the famous case Basic Inc. $v$. Levinson, 'silence, absent a duty to disclose, is not misleading under Rule 10b-5."').

85. See Securities Exchange Act of 1934 § 13, 15 U.S.C. $§ 78 m$ (2000 \& Supp. 2004).

86. See id. 
restricted shareholders about the company's valuation. The restrictions obstruct the picture of the market valuation of the company's shares, and the real decisions of the initial investors whether to maintain their holdings or dismiss them are not revealed to the public.

\section{Economic Stake and Length of Investment}

Rule 144 intends to provide a safe harbor to sales that do not involve the issuer. Rule 144, however, restricts investors much more than is necessary to ensure that the registration requirements are not circumvented by the issuer. It seems that Rule 144 ignores the general assumption of economic risks by private placement investors purchasing their shares before the IPO and that Rule 144 thus excludes from the safe harbor such shareholders unless they have held the shares for a lengthy time.

No investor can assume with absolute certainty that the company it invests in will succeed in going public, let alone succeed shortly after the closing of the investment. A shareholder who purchases shares before the company goes public assumes the full risk of the company's failure to finalize a registration and become public. Even mezzanine investments, which are venture capital investments in relatively advanced companies that have passed the start-up stage, though just barely, and are on the verge of going public, are risky economic private investments.

Investors that purchased shares in a mezzanine round of investment, when it seemed that the company was about to go public and its management was actively planning such a move, did not always see the company go public. Those investors were often left with shares of a private company without the ability to realize profits, or even to sell the shares for any price, for years thereafter. This was especially the case for investment transactions that closed shortly before the burst of the technology bubble. Thus, the risk associated with participating in a private placement transaction is so significant that it seems unnecessary to add another deterrent, such as a holding-period restriction, merely because of the concern that the investor, without assuming the economic risks of its investment, might be a "conduit[] for sale to the public of unregistered securities, directly or indirectly, on behalf of an issuer."

87. Preliminary Note to Rule 144, 17 C.F.R. $§ 230.144$. 
The concern of Rule 144 with restricted shares that were acquired prior to the IPO becomes irrelevant after the filing of the IPO registration statement. The registration statement has to include a detailed account of the restricted shares and the rights attached thereto. ${ }^{88}$ The filing requirements associated with going public are intended to inform the public and, in a sense, rectify and redeem those previously acquired shares for the purpose of the 1933 Act. A resale transaction by a private investor that acquired its shares prior to the IPO is not similar to a transaction in which securities are issued by the company itself following the IPO. The latter involves a change in the capital structure of the company and a decision to raise more funds by the company, while the former does not.

Following the IPO, a sale of shares purchased prior to the IPO should not be viewed as a distribution within the meaning of the 1933 Act. This should be the case even if the shares were purchased as a mezzanine investment, and even with the intent to sell such shares in the future, as long as it is done in the manner specified under Rule 144. The Rule imposes sufficient conditions for the application of the safe harbor without the need for the onerous holding-period and selling-volume restrictions. Indeed, Rule 144(f) imposes a manner-of-sale condition that prohibits solicitation of orders to buy and requires the use of a broker or a market maker for the sale. ${ }^{89}$ The payment to such broker cannot exceed the usual and customary broker's commission. Rule 144(c) also adds a current public information requirement that permits sales, subject to the other requirements of Rule 144, only if the company has complied with the periodic reporting requirements under the 1934 Act. $^{90}$

Chronologically, there are two types of transactions: (1) private placements occurring prior to the actual IPO; and (2) issuances not involving any public offerings that take place following the IPO. ${ }^{91}$ One might want to distinguish between securities purchased in a private placement before the IPO and those purchased after the IPO. With regard to issuances preceding the IPO, the fact that the registration statement must include a detailed description of such issuances should be enough. When it comes to issuances

\footnotetext{
88. See 15 U.S.C. $\$ 77$ aa (2000).

89. 17 C.F.R. $\$ 230.144(f)$.

90. Id. \$230.144(c).

91. See id. $§ 230.144(\mathrm{a})(3)$.
} 
following the IPO, there seems to be a more justified concern about the issuer trying to avoid an additional registration by using exempt private placements with the intent that public resale will soon follow. In such an event, if the new shareholders are able to resell their shares in the market easily, the company might be able to circumvent the requirements associated with another public offering. However, the "manner of sale" condition of Rule $144^{92}$ and the current-information requirement, ${ }^{93}$ along with the Form 8 -K reporting requirements, ${ }^{94}$ seem to ease the concern especially regarding the former type of transactions.

\section{Market Stabilization and Limitation on Sales}

The restrictions of Rule 144 do not contribute effectively to the stabilization of the market and prevention of extreme price fluctuations. The restrictive effect of Rule 144 on the volume of trading of the company varies with the number of restricted shareholders that the company has. The selling-volume restriction is not sensitive to the effect of the aggregate sales by all the restricted shareholders on the trading volume of the company. Thus, Rule 144 does not effectively control the aggregate increase in the volume of trading because it only limits sales by each individual shareholder and ignores the number of shareholders. ${ }^{95}$

Furthermore, in spite of the sale restrictions of Rule 144, underwriters find it necessary to administer lock-up agreements that contractually limit the sale of stock acquired before the IPO for the purpose of stabilizing the market. ${ }^{96}$ The ubiquity of lock-up agreements indicates that Rule 144 fails to stabilize the market. The underwriters' lock-ups are different from Rule 144's requirements both in the length of time during which the sale is restricted and in the amount of shares that are restricted. This suggests that while stabilizing the market is desired, ${ }^{97}$ it can be

92. Id. $§ 230.144(\mathrm{~b})$.

93. Id. $\$ 230.144(\mathrm{c})$.

94. Id.

95. For a numerical example, illustrating the selling-volume restriction's ineptitude to prevent significant volume increases following sales of restricted stock, see infra Part III.C.

96. See SEC, Initial Public Offerings, Lockup Agreements, http://www.sec.gov/ answers/lockup.htm (last visited Mar. 8, 2007) (describing the typical lock-up agreement).

97. Stabilizing the market is especially important in the immediate period that follows the IPO. See 1 HAZEN, supra note $6, \S 6.1$. 
achieved by the market without external intervention. Rule 144's attempt to stabilize the market is thus redundant at best. Comparing the requirements of Rule 144 and the customary lockup agreements suggests that Rule 144 is excessively restrictive because it imposes a holding period that in some cases may last longer than the customary lock-up period of six months. ${ }^{98}$

Not only does Rule 144 fail to achieve its intended purpose, as this Part shows, its restrictions have additional negative effects. Such effects, which will be described in the next section of this article, include increases in the cost of raising capital and inefficient investment incentives.

\section{Distortions CAUSED By RUle 144}

Rule 144, in its current form, induces inefficient behavior and provides the wrong incentives. To be sure, Rule 144 is harmful to investors that hold restricted shares because such investors are directly restricted by it. Rule 144 adversely affects the public because they may be less informed when purchasing the company's shares. ${ }^{99}$ The company is also hurt because Rule 144 makes it more difficult for the company to raise capital. The discussion in this Part will focus on Rule 144's effects on the company.

Section A of this Part describes the increase in the cost of capital incurred by emerging companies because of Rule 144. The cost increase is a direct result of the restrictions on the investors' ability to liquidate their investment. Section B discusses the effect of the reduced liquidity on the ability of the VCs to finance investments in inefficient capital markets. The reduction in available funds hurts the ability of emerging ventures to receive financing from VCs. Section C presents the problem of suboptimal investment that Rule 144 creates. It also describes the pressure not to invest significant amounts in a single start-up. The section further describes the costs that are generated because of the inefficiently low levels of investments that each $\mathrm{VC}$ is willing to invest in a single start-up. Such costs include higher search costs, higher investigation costs, reduced monitoring, and the increased risk of conflicts of interests. Section D describes the negative

98. The underwriters' six month lock-up period starts at the IPO. The Rule 144 holding period, on the other hand, starts at the time the stock is originally purchased. Thus, the effective length of Rule 144 restriction on sale as of the IPO depends on the time of purchase.

99. See supra Part II.E.1. 
effects of Rule 144 on the financing decision of the company. The Section shows how Rule 144 is likely to play a pivotal role in the company's decision of when and where to go public.

\section{A. Increase in the Cost of Capital}

The ability of a shareholder to sell securities freely is valuable. The market views illiquidity as a cost. ${ }^{100}$ The investor faces the risk that, should it be in need of funds while its investments are illiquid, it will be forced to bear borrowing costs or lose a promising new investment. In addition, illiquidity exposes the shareholder to the risk of losing the value of its investment. Reducing a VC's liquidity increases its risk-bearing costs. It is faced with the risk that the value of its shares will fall, yet it will be prevented from divesting its investment and from diversifying the risk by lowering the amount of such shares in its portfolio. In effect, the $\mathrm{VC}$ will be forced to choose different venues to mitigate the risk. VCs are particularly sensitive to liquidity since they are expected to convert their investments into cash or marketable securities after a relatively short time. $^{101}$

The restrictions of Rule 144, however, impede the liquidity of the holders of restricted securities. Such holders are artificially forced to wait before they are allowed to sell their shares, even though a market for their shares already exists. The holdingperiod restriction renders the restricted shares completely illiquid for the duration of the holding period.

The extent of the liquidity that is permitted by the sellingvolume restriction is basically determined by two factors. The first factor is the volume of trading of the company's shares ${ }^{102}-\mathrm{a}$ variable over which the shareholder has no direct control and

100. See, e.g., David Goldreich et al., The Price of Future Liquidity: Time-Varying Liquidity in the U.S. Treasury Market, 9 REv. FIN. 1 (2005) (finding that the value of securities depends on their expected liquidity); Viral V. Acharya \& Lasse H. Pedersen, Asset Pricing with Liquidity Risk, 77 J. FIn. ECON. 375 (2005) (showing that the securities' price depends on the liquidity risk of the securities).

101. See, e.g., Fenn et al., supra note 23, at 29 (studying the private equity markets and describing the VCs' investing behavior); D. Gordon Smith, The Exit Structure of Venture Capital, 53 UCLA L. REV. 315, 345 (2005) ("Exit is not merely optional for venture capitalists. Most venture capital funds have a fixed life . . . Any venture capitalist who desires to remain in business, therefore, must successfully raise funds, invest them in portfolio companies, then exit the companies and return the proceeds to the fund investors ....").

102. For a description of Rule 144(e)'s volume restriction, see supra notes $66-68$ and accompanying text. 
which often cannot be accurately predicted. The other factor is the number of shares held by such shareholder. The liquidity of the shareholder is positively correlated with the first factor-the volume of trading-and negatively correlated with the latter factor-the number of shares the shareholder owns. As long as the volume of trading is not exceptionally high and the holdings of the shareholder are not extremely small, the selling-volume restriction is responsible for the partial illiquidity of the shareholder.

As described below, in addition to liquidity constraints, the investors incur further costs as a result of Rule 144. All of the investing costs that the investors incur are taken into account when they negotiate with the start-up. In order to compensate themselves, the investors shift at least part of the excessive cost to the company and increase the return they demand from it. This raises the cost of capital with which start-ups have available. Thus, a start-up that wishes to raise capital is faced with more obstacles. The start-up is forced by the investors to bear the higher costs that the restrictions of Rule 144 generate. Hence, the increased cost of capital makes it more expensive and difficult for start-ups to receive financing.

\section{B. Reduction in Resources Available to Emerging Ventures}

Reducing the liquidity of investors locks their resources in a mature investment while hindering their ability to support an alternative new investment in imperfect capital markets. It would be more efficient, though, if the investors that are less risk averse and more capable of assessing the risk supported the new investment while the public invests in the mature investment. This is especially relevant to resources of investors like VCs that support emerging start-ups in their initial steps. In these initial stages, it is too risky for the unsophisticated public to invest because it lacks the needed expertise. Due to market inefficiency, VCs might not be able to raise enough funds from institutions to allow them to invest at an optimal level. Restricting the ability to liquidate VCs' investments once the companies are public is likely to further reduce the availability of funds for new investments. Thus, one of the outcomes of Rule 144 is that fewer resources are available for emerging ventures. 


\section{Suboptimal Investment}

Rule 144 discourages investors from acquiring large amounts of a single company. Investors are likely to prefer to invest smaller amounts in more companies, rather than larger amounts in fewer companies. This is because the liquidation rights granted under Rule 144's safe harbor are disproportionate to the amount of restricted shares a shareholder has.

The formula to calculate the maximum amount of restricted shares a shareholder may sell under Rule 144 does not take into account how many shares the shareholder owns. Rule 144 does not distinguish among shareholders; it states the maximum allowed amount per shareholder without taking into account the size of its holdings, the number of other holders of restricted shares or the aggregate amount of restricted shares. ${ }^{103}$ Since Rule 144 allows each shareholder to sell up to the same maximum amount, one shareholder may liquidate one hundred percent of its holdings while a bigger shareholder may only liquidate a small fraction of its holdings.

In contrast, customary contractual arrangements that are in effect prior to the IPO link rights of shareholders to their percentage holdings (e.g. participation in first refusal rights-the right to participate in future issuances of the company and in cosale rights- the right to participate in a sale transaction by certain shareholders). ${ }^{104}$ Market behavior in similar circumstances indicates an efficient contractual arrangement.

Rule 144 links the right to sell with the shareholder rather than with the share. Each restricted shareholder is allowed to sell the same amount regardless of the size of its holdings. ${ }^{105}$ Thus, the last share purchased is accompanied by a much higher risk of illiquidity than the first. After a certain amount of investment, the shareholder knows that he or she will not be able to use the safe harbor of Rule 144 for selling any of the new shares that it purchases.

Consider the following example. To illustrate the effect of Rule 144, let us look at two hypothetical companies: Company A and Company B. Company A has one restricted shareholder who

103. See 17 C.F.R. $§ 230.144($ e) (2).

104. To be sure, other contractual arrangements that are not strictly financial, such as veto rights and rights to nominate directors, often are not proportionate to the shareholders' percentage holdings.

105. Id. 
has 100 restricted shares. Company $\mathrm{B}$ has ten restricted shareholders owning ten restricted shares each. Other than that, the two companies are similar in all respects. Assume that the average weekly trading volume for the last four weeks was ten shares for both companies. Let us further assume that all of the restricted shareholders of both companies are eager to liquidate their respective holdings.

The single restricted shareholder of Company A will sell ten shares in the market, increasing the volume of traded shares by ten. At the same time, the ten restricted shareholders of Company B will each sell ten shares, accumulating to a total of 100 shares. We can see that Company B will experience an increase in the volume of trading of 100 shares, as opposed to only a ten shares increase in the volume of trading of Company A. This result shows the weakness of Rule 144 in stabilizing the market; it does not effectively control the increase in the trading volume. Thus, Rule 144 does not effectively prevent excessive price pressure and market disruption. ${ }^{106}$

\begin{tabular}{|c|c|c|c|c|c|}
\hline Company & $\begin{array}{c}\text { No. of } \\
\text { Rest. } \\
\text { Shldrs. }\end{array}$ & $\begin{array}{c}\text { Shares } \\
\text { per } \\
\text { Shldr. }\end{array}$ & $\begin{array}{c}\text { Total } \\
\text { Rest. } \\
\text { Shares }\end{array}$ & $\begin{array}{c}\text { Rule 144 } \\
\text { Sale Limit } \\
\text { per Rest. } \\
\text { Shldr. }\end{array}$ & $\begin{array}{c}\text { Total } \\
\text { Shares } \\
\text { Sold }\end{array}$ \\
\hline A & 1 & 100 & $\begin{array}{c}100 \\
(1 \times 100)\end{array}$ & 10 & $\begin{array}{c}10 \\
(1 \times 10)\end{array}$ \\
\hline B & 10 & 10 & $\begin{array}{c}100 \\
(10 \times 10)\end{array}$ & 10 & $\begin{array}{c}100 \\
(10 \times 10)\end{array}$ \\
\hline
\end{tabular}

Rest. $=$ restricted; Shldr. $=$ shareholder

Furthermore, as we can see from our example, Company B's restricted shareholders were able to liquidate all of their restricted holdings, while Company A's restricted shareholder was only able to liquidate a fraction of her restricted holdings-only ten percent. If she had diversified her investment and partially invested in Company B instead of continuing her support of Company A, she would have increased her liquidity. Had she invested, for example, in ten similar companies, buying ten shares in each, instead of just focusing on Company A, she would have enjoyed full liquidity.

Rule 144, therefore, has the effect of restricting the amount an

106. See supra Part II.E.3. 
investor is willing to invest in one company, though it might be preferable and more cost-efficient to have subsequent investments by this same investor. This effect of Rule 144 can provide at least a partial explanation of the empirical findings that have puzzled researchers. According to these findings, while venture capital more than doubled during the 1980s, the average size of investment increased by only forty percent during the same period, in spite of the market-wide acknowledgement that efficiency requires an increase in the size of investments more than the increase in the number of investments. ${ }^{107}$

It may be more efficient to have follow-on investments by the same investor, and it is, therefore, inefficient to limit the amount of shares an investor can sell under the safe harbor in the manner that Rule 144 does. The costs of smaller-than-desirable investments in start-ups may involve: (1) additional searching costs by both the investors and the start-ups; (2) excessive due diligence costs; (3) suboptimal monitoring; and (4) increased conflicts of interest between investors and start-ups.

\section{Higher Search Costs}

Since Rule 144 has the effect of reducing the amount an investor is willing to invest in a single company, it is not enough to find a single promising venture in which to invest and reinvest. The investors incur additional search costs because they have to continue to look for additional investments. Similarly, the company has to look for more investors. Because one investor may not be willing to fund the company sufficiently, the company has to look for and deal with more than one potential investor. This increases the search costs of the company and the company's cost of capital.

\section{Higher Investigation Costs}

After an investor finds a company to invest in, it conducts detailed due diligence before finalizing the investment. Unlike new investors, existing investors do not need to conduct costly,

107. See Fenn et al., supra note 23, at 14 ("Many market participants suggest that as the size of partnerships increases, increasing the average size of investments is more efficient than increasing the number of investments . . . Somewhat surprisingly, data on investments suggest only moderate shifts toward larger investments ...."). 
extensive due diligence on the company. The existing investors already conducted such expensive research at the time they first invested in the company. The existing investors are already shareholders of the company and often have board representation. Thus, they are kept informed of any material changes that take place since the original investment and are considerably familiar with the company. The review of the company that they will require before reinvesting, if any, will be more focused and less expensive. Because Rule 144 has the effect of increasing the number of new investors rather than reinvestments, it increases due diligence expenses that could have been prevented if existing investors reinvested.

\section{Reduced Monitoring}

The preinvestment screening process and the structure of the financial contracts provide VCs with unique access to information that facilitates monitoring. The monitoring activities themselves, however, are costly. ${ }^{108}$

The alignment of interests of the company with those of an individual shareholder declines with the decrease in percentage holdings of the latter. The lower the stake of an investor in the company, the lower the investor's incentive to monitor the operation of the company's management. An investor that invests less in a company internalizes less of the benefits of its own monitoring of the company. Hence, Rule 144 might lead to less monitoring than is optimally desired.

\section{Increased Risk of Conflict of Interests}

The risk of a conflict of interest between an investor and one of its portfolio companies caused by a potential conflict between two portfolio companies increases with the addition of more portfolio companies in which an investor is invested. The investor might inefficiently favor one company in place of the other because it is invested more in the former.

This misalignment of interests between the company and the investor, aggravated by the increase in the number of ventures backed by the same investor, may provide the investor with incentives to steer the company toward an inefficient result. To be

108. See Denis, supra note 2, at 305 (reviewing the literature on VCs' monitoring activities and the effects of the associated costs). 
sure, such behavior will be done in a subtle way, without raising the suspicion of the management of the company that is unaware of any specific conflicting interests. The special role that VCs play in the emerging venture's business, as described above, ${ }^{109}$ allows the VCs to influence the company opportunistically without raising doubts as to their hidden intentions.

\section{Distortion of the Company's Financing Decisions}

A private company, looking to finance its operations, can try to do so in several ways. It is likely to raise money in private financing transactions, in a public offer, or in a merger and acquisition deal (M\&A). The decision how to finance the operations is likely to be influenced by Rule 144, resulting in a less efficient choice. This Section describes how, because of Rule 144, a company may inefficiently decide to refrain from or delay going public ${ }^{110}$ and it may, under certain circumstances, go public prematurely. ${ }^{111}$ Furthermore, it may choose to be traded on a specific stock exchange because of Rule 144's restrictions, not because of the merits of the exchange. ${ }^{112}$

\section{Delay in Going Public}

Even though it may be more efficient, the company might postpone or decide against going public because of investor pressure. The investors may ask the company to find a different means of financing that provides easier liquidity prospects for the investors, such as M\&A, which does not rely on Rule 144's safe harbor. Liquidity is especially important to VCs that structure their investment fund as a short-term investment vehicle. ${ }^{113}$ Accordingly, in the case of a start-up by the name of PowerDsine, it was reported that investors preferred a sale of their portfolio company to an IPO, even though the value of the company for the purposes of an IPO was about twenty-five percent higher than the valuation of the company that was negotiated for the purposes of a sale. ${ }^{114}$ Thus,

109. See supra Part II.A.

110. See infra Part III.D.1.

111. See infra Part III.D.2.

112. See infra Part III.D.3.

113. See Smith, supra note 101, at 316 ("The ability to control exit is crucial to the venture capitalist's business model of short-term funding of nascent business opportunities.").

114. See Sophie Shulman, PowerDsine Keeps Silent on Talk of Sale, HaARetz.com, 
the liquidity constraints of a shareholder of a publicly traded company, aggravated by Rule 144 restrictions on sale, may motivate investors to prefer lower-value transactions over higher-value transactions and may influence the company not to go public.

\section{Going Public Too Soon}

The company might alternately be forced to go public too soon because the alternative private placement has become too expensive. In general, the increase in the cost of private equity, due to the liquidity constraints imposed on investors by Rule 144, makes it harder for the company to find investors. Furthermore, the old investors of the company might be reluctant to reinvest after having reached a certain level of investment because of the selling-volume restriction of Rule $144 .^{115}$ After failing to secure private financing at an affordable price, the company is likely to turn to the public option.

Even though there are benefits from becoming a public company, the process involves notable costs and risks. The preparation of the registration statement by itself is a demanding task. Once the company is registered, it is exposed to additional risks and costs, such as those required to comply with the mandatory periodic reporting. The preparation of such reports is expensive, consumes management time, exposes those involved to liability, and divulges information that a private company may keep confidential. In addition, a public company is more likely to be pressured to show quick returns, rather than focus on the longterm performance of the company.

\footnotetext{
Dec. 3, 2004, http://www.haaretz.com/hasen/objects/pages/PrintArticleEn.jht ml?itemNo=403941.

PowerDsine is engaged in talks concerning the sale of the company . . . . $[\mathrm{T}]$ he negotiations are centering on a company value of $\$ 170-200$ million ... . While the company talks of a sale, it is also in the process of an IPO on the Nasdaq according to a value of $\$ 250$ million before the money. The company aims to raise $\$ 70-80$ million . . . . In the event that PowerDsine reaches an agreement with the potential . . . buyer, company shareholders are expected to opt for the sale rather than the stock issue. While the sale would allow the shareholders to immediately realize their holdings, the public issue comes with a risk of a drop in the value of their investment. 


\section{Inefficient Choice of Stock Exchange}

Empirical studies have found that the selling-volume restriction of Rule 144 is an important factor that influences the choice of stock exchange and often results in an inefficient choice for the traded company. ${ }^{116}$ Because of Rule 144, companies often choose the Nasdaq as the venue for their initial listing, ${ }^{117}$ and companies traded on the Nasdaq often do not transfer their shares to the NYSE. This is due to the difference in measuring trading volumes. On the Nasdaq, a transaction may result in a reported volume of twice the size, compared to the reported volume of a similar transaction on the NYSE because of the different methods of trading. ${ }^{118}$ Despite the potential increase in share value associated with listing on the more prestigious NYSE, ${ }^{119}$ and lower trading costs, ${ }^{120}$ companies with investors that intend to sell a large number of restricted shares following the IPO, such as VCs, ${ }^{121}$ tend to prefer to register on the Nasdaq. ${ }^{12}$

As a rough estimate for some of the costs borne by shareholders and indirectly caused by Rule 144, one can look at the excessive costs incurred as a result of trading on the Nasdaq rather than trading on the NYSE. The aggregate cost inflicted by Rule 144 's restrictions is at least as high as the cost of the measures taken by the shareholders in order to avoid the restrictions of the Rule.

Huang and Stoll calculated the excessive cost of transacting on

116. See Wan, supra note 26, at 39; see also Anderson et al., supra note 26, at 9 ("The IPO listing decision is strongly related to subsequent Rule 144 selling activity.”).

117. See Anderson et al., supra note 26, at 13 ("Many firms that are eligible for listing on the NYSE choose, instead, to have their shares traded on Nasdaq.").

118. On the Nasdaq, dealers often take position (buy/sell) as opposed to merely acting as an agent who matches and completes the transaction. The result is a doubling of the reported volume for a similar transaction. See Wan, supra note 26, at 14; Anderson et al., supra note 26, at 4.

119. See Wan, supra note 26 , at 8 ("[C] ompanies usually perceive listing on the NYSE is prestigious and can enhance their firm visibility.”); Anderson et al., supra note 26, at 2 ("Numerous studies suggest that firms benefit from being listed on the New York Stock Exchange (NYSE).”).

120. See Wan, supra note 26 , at 2 ("[T] he bid-ask spread for Nasdaq-listed stocks is larger than comparable NYSE-listed stocks. This implies that stocks of companies that ... list on the Nasdaq bear larger transaction costs ....").

121. See Anderson et al., supra note 26, at 11 ("[T] he presence of venture capital backing of the IPO firm significantly increases both the number of sellers of restricted shares and the amount of such selling after the IPO.”).

122. Id. at 9 ("IPO firms that choose to list on the NYSE have significantly fewer insiders disposing of restricted shares in the two years following the IPO, and insiders in NYSE IPOs sell significantly fewer restricted shares overall.”). 
the Nasdaq rather than on the NYSE in $1991 .^{123}$ They found a difference of 10.8 cents per share in the "effective" bid-ask spreads. ${ }^{124}$ This number can be used as a conservative measure ${ }^{125}$ for the calculation of the higher costs that investors chose to incur in order to circumvent some of the restrictions of Rule 144. The corresponding average monthly trading volume per company traded on the Nasdaq is 3,681,500 shares, as calculated by Huang and Stoll, using a sample comprised of the largest Nasdaq stock matched to NYSE stock. ${ }^{126}$ Multiplying the difference in the effective spreads by an estimate of the yearly volume of trading of a hypothetical company traded on the Nasdaq ${ }^{127}$ results in a yearly estimated total loss of about $\$ 5$ million. Capitalizing the excessive yearly costs over the entire life of the firm, assuming no future switch to the competing exchange and no change in the difference between the exchanges, provides the estimated lifetime loss by the shareholders of a company traded on the Nasdaq, rather than on the NYSE, to be about $\$ 60$ million. ${ }^{128}$

While this shows another important inefficient behavior that is a direct result of Rule 144, it must be noted that this result can be fixed in a relatively easy manner. To fix this specific distortion, it is enough that the method by which the volume of trading is measured for the calculation required by Rule 144 will be regulated so that the choice of stock exchange will no longer affect the selling rights under the Rule, and this does not call for abolishing the restriction altogether. But this empirical result shows the extent to which shareholders will go to avoid Rule 144's restrictions and indicates the significance of the sale restrictions and the need to consider the other distortions that it may cause.

123. See Roger D. Huang \& Hans R. Stoll, Dealer Versus Auction Markets: A Paired Comparison of Execution Costs on NASDAQ and the NYSE, 41 J. FIN. ECON. 313 (1996).

124. Id. at 325. "The cost of executing transactions is higher on Nasdaq than on the NYSE by every measure we calculate." Id. at 351. "The contrast between the two markets is quite striking. In each trade size category, the quoted spread on Nasdaq is nearly twice the quoted spread on the NYSE." Id. at 324.

125. Id. at 324-25.

126. Id. Table 1 at 321 .

127. $(10.8 \div 100) \times \$ 3,681,500 \times 12=\$ 4,771,224$.

128. $(\$ 4,771,224 \div 0.0814)=\$ 58,614,545$. The 8.14 discount rate used for the capitalization is the long term interest rate in effect at the date of the data used for the empirical findings. Huang \& Stoll, supra note 123. The rate used is the 1991 thirty-year treasury constant maturity rate as reported by the Federal Reserve; these rates are available on the Federal Reserve website: http://www.federalreserve.gov/ releases/h15/data/Annual/H15_TCMNOM_Y30.txt. 


\section{TOWARD A MARKET FORCES DRIVEN REGIME}

This Part discusses the possibility of replacing the restrictions of Rule 144 with a market forces driven regime in which each company can decide whether to restrict the re-sale of pre-IPO acquired shares and the extent of such sale restriction. Such a regime would be more efficient and would eliminate the distortions that are caused by the restrictions of Rule 144. This Part further considers the possibility that a policy prohibiting any restriction on re-sales serves the interests of the public.

Currently, underwriters contractually prevent sales by shareholders who purchased their shares prior to the IPO usually for a period of 180 days following the IPO. ${ }^{129}$ This contractual mechanism, aimed at stabilizing the market, is known as underwriters' lock-up. At the time of their investment, investors undertake to be bound by such lock-ups, should the underwriters deem it advisable for the success of the company's IPO.

The one-year holding period of Rule 144 might restrict sales for a longer time after the IPO than the customary 180-day lock-up period beginning at the IPO and administered by underwriters. Since Rule 144's holding period starts from the original purchase date, the selling restriction following the IPO depends on how much time has lapsed between the original purchase date of the shares and the IPO. The holding-period restriction of Rule 144 might be unnecessary or even inefficient for the purpose of stabilizing the market because it may restrict sales after the IPO for longer than the 180 days of the underwriters' lock-ups. ${ }^{130}$ If a longer period of sale restriction is needed in order to stabilize the market for the company's shares, an efficient market will contractually administer such longer restriction because underwriters would have demanded it as part of their attempt to stabilize the market to ensure the success of the public registration of the company's shares. If an economic justification to restrict the

129. See SEC, supra note 96.

130. The time period of at least one year seems inconsistent and excessive in comparison with the mere six-month period of Section 16 of the Securities Exchange Act of 1934 that fends off abuse of inside information in short-swing transactions. Securities Exchange Act of 1934 § 16(b), 15 U.S.C. § 78(p) (2000 \& Supp. 2004). Both of these periods-the six months of Section 16 and the one year of Rule 144-may be arbitrary. A six-month period, however, seems to have a market validation as an efficient period for stabilizing the market and preventing insiders from trading because it is the customary period contractually enforced by underwriters as a lock-up period. 
sale of shares following the initial public offering existed, as the one stated in the SEC's preliminary note to Rule $144,{ }^{131}$ such restrictions would have been contractually agreed upon and enforced, driven by market forces similar to those behind the administration of the underwriters' lock-up.

Moreover, contractual restrictions have the advantage of being specifically tailored to fit the different needs of each company. Each company may require a different restriction in order to create and stabilize a public market for its shares. Such a restriction should be more flexible and take into account, inter alia, each company's specific capital structure, size, and various accounting, business, and reputational characteristics. For example, significantly promising companies may not need any sale restrictions in order to stabilize the market for their shares. The shareholders of such companies should be allowed to resell their shares freely. On the other hand, companies that are more susceptible to price fluctuations can restrict their shareholders contractually, similarly to the underwriters' lock-ups. Unlike the Rule 144 selling-volume restriction, the contractually administrated restrictions on resales will be sensitive to the number of restricted shares and the total effect of such sales. The companyadministrated resale rights can also discriminate shareholders based on the importance each shareholder assigns to liquidity, and the company can grant the re-sale rights efficiently, based on the price each shareholder is willing to pay for liquidity.

A company-initiated lock-up, such as the underwriters' lockups, is likely to be more efficient than Rule 144's restrictions, as previously explained. It may be, however, that a market free of any temporary artificial limitations on the supply of shares is preferable. Indeed, the administration of a lock-up period following an IPO is a deeply rooted custom in the going-public practice. The fact that it is the underwriters' custom, by itself, however, cannot provide a justification for its existence. Other underwriters' practices, such as the custom of under-pricing the offer of "hot" IPOs for the benefit of selected friends who are granted privileged access to lucrative public placements, have been challenged and their legality questioned. ${ }^{132}$

131. Preliminary Note to Rule 144, 17 C.F.R. $\$ 230.144$ (2006).

132. See Matt Marshall, Opening Up the IPO to Smaller Investors: Concept Catching the Interest of Bay Area Tech Companies, SAN Jose Mercury News, Sept. 22, 2003, at 1E ("Ritter, the University of Florida professor . . . says . . . there's no good 
The interaction between the two underwriters' practices-the under-pricing practice, which is known as "spinning" or as "the friends of Frank," and the lock-ups practice-may shed a different light on the use of the underwriters' lock-ups. The lock-ups may well be instrumental in enabling those who were granted privileged access to the underpriced IPOs to realize quick gains before more shares are entered into the market. Thus, it seems that these underwriters' lock-ups are, in fact, driven by private dealing.

Furthermore, shareholders have an inherent interest in avoiding price reductions triggered by a sudden large increase in the supply of shares in the market that the shareholders themselves might cause. The concern about lowering the price of the shares in the midst of a sale may lead to self-restraint. Rational shareholders, such as the sophisticated VCs that purchase shares before the IPO, will therefore refrain from hastily flooding the market with substantial amounts of shares, even in the absence of any legal obligation.

In addition, it is foreseeable and natural that some increase in the supply of the stock will occur following the IPO because old investors are likely to realize profits by liquidating some of their original investment, provided that there is no restriction at this time. Since this is known at the time of the IPO, it should not cause a significant effect on the stock price later. If the old investors wish to conduct extensive sales, in an amount not reasonably foreseen at the time of the IPO, the stock price should reflect such conduct to the full extent, in the same manner as it reflects any exogenous changes in the share supply. Artificially delaying such sales, either by Rule 144 or by using underwriters' lock-ups, however, does not seem to benefit the public, but rather conceals important information from the public. Thus, if the underwriters' lock-ups are, in fact, driven by private dealing, and efficiency requires that there will be no such contractual restriction, Rule 144, which adds sale restrictions, is highly inefficient and may serve questionable practices such as the IPO under-pricing to the public's detriment.

explanation for underpricing 15 percent or more in a fair system . . . All local tech IPOs this year have enjoyed first-day jumps of 25 percent or more."); Andrew Ross Sorkin, Banker's Trial Gives Glimpse into Close Ties of Tech Boom, N.Y. TIMES, Oct. 13, 2003, at C1 ("[B]ankers often tried to attract new business by offering corporate executives access to hot initial public offerings ....”). 


\section{CONCLUSION}

Rule 144, in its current form, is inefficient and has distorting effects on the stock market and on the economy. Its negative effects especially concern emerging ventures. Both the sellingvolume restriction and the holding-period restriction of Rule 144 impose a significant burden on companies. An increase in the cost of raising capital and an incentive to invest in suboptimal levels are two of the main problems caused by Rule 144's restrictions.

In addition, the selling-volume restriction and the holdingperiod restriction fail to properly address the concerns that are at the basis of Rule 144's promulgation. The restrictions might even cause the purchasing public to be less informed. Furthermore, the restrictions do not effectively govern the trading volume increase, and their contribution to market stabilization is limited at best. Thus, I propose abolishing the main restrictions of Rule 144 and allowing market forces to reach an efficient mechanism. 